\title{
Central processing of afferent renal pathways-significance and implications
}

\author{
Kristina Rodionova ${ }^{1} \cdot$ Roland Veelken ${ }^{1,2}$ (D)
}

Received: 11 August 2020 / Revised: 11 August 2020 / Accepted: 4 September 2020 / Published online: 12 September 2020

(C) The Author(s) 2020

Fen Zheng and his co-authors investigated in their article Interleukin-1 $\beta$ in hypothalamic paraventricular nucleus mediates excitatory renal reflex the central pathways of a sympathetic excitatory reflex, which is triggered by renal afferent nerve fibers. The authors had already described this reflex in more detail before: a direct infusion of capsaicin into the renal interstitium resulting in an increase of sympathetic nerve activity to the kidneys. In their recent work addressing central nervous mechanisms, the authors focused on the paraventricular nucleus of the hypothalamus, which plays an important role in the processing of various peripheral afferent information, which in turn participate in the generation of central sympathetic outflow. With regard to their specific question, the authors convincingly demonstrated that sympathetic activation following administration of capsaicin directly into the renal interstitium is mediated via IL-1 $\beta$ in the paraventricular nucleus of the hypothalamus.

The investigation of neurophysiological structures like the paraventricular nucleus of the hypothalamus is important because the central pathways integrating afferent and efferent renal nerve activity are not well understood. Clinical studies suggest an important role of renal sensory afferent innervation in the regulation of efferent sympathetic tone. In patients with hypertension and end-stage kidney disease, peripheral sympathetic activity remained increased after renal transplantation. Peripheral sympathetic tone decreased only in patients who had additionally undergone bilateral nephrectomies of the failing kidneys [7].

This article is a commentary to the original article https://doi.org/10.1007/ s00424-020-02461-7

Roland Veelken

roland.veelken@uk-erlangen.de

1 Department of Internal Medicine 4 - Nephrology and Hypertension, Friedrich-Alexander University Erlangen, 91054 Erlangen, Germany

2 Department of Internal Medicine 4 - Nephrology and Hypertension, Paracelsus Private Medical School Nuremberg,

Nuremberg, Germany
At first glance, it may seem surprising why an interleukinlike IL-1 $\beta$ should play such a prominent role in processing afferent neuronal input for the generation of central sympathetic outflow. However, one should bear in mind that the immune system and many visceral organs are autonomously innervated quite densely [8]. The influence of the autonomous innervation on acute and chronic inflammation with respect to various organs like liver, skin, the joints, and kidneys has been repeatedly reported $[1,2,10]$. The matter has become more intriguing since afferent renal nerve fibers will not only influence central sympathetic outflow [4]. Rather, afferent nerve fibers in general are also known to release neuropeptides like CGRP and SP influencing local circulation and interfering with immune processes [3]. Hence, catecholamines as well as the mentioned peptide transmitters may contribute to neuroimmune interactions while also influencing the activity of efferent sympathetic and afferent pathways. In this respect, pro-inflammatory cytokines like IL- $1 \beta$ were described to influence the central nervous system via the circulation or stimulate peripheral afferent nerve fibers [6].

If capsaicin was not injected into the renal tissue but directly into the organ via the renal arteries, a long lasting sympathetic depression [5] and no sympathoexcitation occurred as described by Fen Zheng and co-authors. The different results are probably due not only to different routes of administration but also touch on the still unsolved question of how renal afferences actually influence the sympathetic nervous system: While decreases in peripheral sympathetic activity after nephrectomy favor sympatho-excitatory afferents from the kidneys [7], we are also presented with further reports that rather support a role of afferent nerve fibers in sympatho-depression [4]. One special example known for a long time are reno-renal sympatho-depressory reflexes which are impaired in spontaneously hypertensive rats [9].

More extensive research will be needed to clarify these last mentioned open points. The fact that there will be no quick and easy explanations in this context is not least due to the observation that afferent nerve fibers always have both mechano- and 
chemosensitive properties, whereby they express a large number of different receptors, quite a few of them with significant involvement in immunological responses.

Acknowledgements Open Access funding provided by Projekt DEAL.

Open Access This article is licensed under a Creative Commons Attribution 4.0 International License, which permits use, sharing, adaptation, distribution and reproduction in any medium or format, as long as you give appropriate credit to the original author(s) and the source, provide a link to the Creative Commons licence, and indicate if changes were made. The images or other third party material in this article are included in the article's Creative Commons licence, unless indicated otherwise in a credit line to the material. If material is not included in the article's Creative Commons licence and your intended use is not permitted by statutory regulation or exceeds the permitted use, you will need to obtain permission directly from the copyright holder. To view a copy of this licence, visit http://creativecommons.org/licenses/by/4.0/.

\section{References}

1. Abdulla MH, Johns EJ (2017) The innervation of the kidney in renal injury and inflammation: a cause and consequence of deranged cardiovascular control. Acta Physiol (Oxford) 220:404416. https://doi.org/10.1111/apha.12856

2. Banek CT, Knuepfer MM, Foss JD, Fiege JK, Asirvatham-Jeyaraj N, Van Helden D, Shimizu Y, Osborn JW (2016) Resting afferent renal nerve discharge and renal inflammation: elucidating the role of afferent and efferent renal nerves in deoxycorticosterone acetate salt hypertension. Hypertension 68:1415-1423. https://doi.org/10. 1161/HYPERTENSIONAHA.116.07850
3. Carlton SM (2014) Nociceptive primary afferents: they have a mind of their own. J Physiol 592:3403-3411. https://doi.org/10.1113/ jphysiol.2013.269654

4. DiBona GF, Esler M (2010) Translational medicine: the antihypertensive effect of renal denervation. Am J Physiol Regul Integr Comp Physiol 298:R245-R253. https://doi.org/10.1152/ajpregu. 00647.2009

5. Ditting T, Freisinger W, Siegel K, Fiedler C, Small L, Neuhuber W, Heinlein S, Reeh PW, Schmieder RE, Veelken R (2012) Tonic postganglionic sympathetic inhibition induced by afferent renal nerves? Hypertension 59:467-476. https://doi.org/10.1161/ HYPERTENSIONAHA.111.185538

6. Exton MS, Herklotz J, Westermann J, Schedlowski M (2001) Conditioning in the rat: an in vivo model to investigate the molecular mechanisms and clinical implications of brain-immune communication. Immunol Rev 184:226-235. https://doi.org/10.1034/j. 1600-065x.2001.1840120.x

7. Hausberg M, Kosch M, Harmelink P, Barenbrock M, Hohage H, Kisters K, Dietl KH, Rahn KH (2002) Sympathetic nerve activity in end-stage renal disease. Circulation 106:1974-1979

8. Jung WC, Levesque JP, Ruitenberg MJ (2017) It takes nerve to fight back: the significance of neural innervation of the bone marrow and spleen for immune function. Semin Cell Dev Biol 61:6070. https://doi.org/10.1016/j.semcdb.2016.08.010

9. Kopp UC, Smith LA, DiBona GF (1987) Impaired renorenal reflexes in spontaneously hypertensive rats. Hypertension 9:69-75

10. Veelken R, Vogel EM, Hilgers K, Amann K, Hartner A, Sass G, Neuhuber W, Tiegs G (2008) Autonomic renal denervation ameliorates experimental glomerulonephritis. J Am Soc Nephrol 19: 1371-1378. https://doi.org/10.1681/ASN.2007050552

Publisher's note Springer Nature remains neutral with regard to jurisdictional claims in published maps and institutional affiliations. 